\title{
Response of Coffee Husk Biochar on Growth of Faba Bean on Nitisol and Soil Nutrients
}

\author{
Alemnesh Sisay ${ }^{1}$, Alemayehu Abebawe ${ }^{2}$ \\ ${ }^{1}$ Department of Natural Resource Management, Holetta Agriculture Research Centre, Holetta, Ethiopia \\ ${ }^{2}$ Department of Natural and Computational Sciences, Ambo University, Ambo, Ethiopia
}

Email address:

sisayalemnesh@gmail.com (A. Sisay)

\section{To cite this article:}

Alemnesh Sisay, Alemayehu Abebawe. Response of Coffee Husk Biochar on Growth of Faba Bean on Nitisol and Soil Nutrients. International Journal of Energy and Environmental Science. Vol. 6, No. 4, 2021, pp. 78-85. doi: 10.11648/j.ijees.20210604.12

Received: July 28, 2021; Accepted: August 10, 2021; Published: August 27, 2021

\begin{abstract}
Soil fertility depletion and the associated soil acidity has a serious problem to crop production in most highland part of Ethiopia Fortunately, this problems can be reclaimed using biochar as soil improvements which can be sequestered in the soil for several years. A pot experiment was conducted to investigate the effects of biochar on soil properties, growth response and nutrient uptake of faba bean. The design employed was a randomized complete block with four replications. The parameters analyzed includes: Trace Metals using DTPA extraction, macronutrient using $1 \mathrm{~N}$ ammonium acetate $(\mathrm{pH}=7)$ extraction. Dry ashing method was used to determine nutrient uptake of plant samples. The studied soil and plant data were collected, using analysis of variance and treatment means were compared at $p$ value 0.05 probability level using list significant difference test. The results showed that application of biochar significantly improved growth of faba bean and soil nutrient content. The highest values for soil chemical parameters such as available phosphorus and exchangeable cations were obtained from the application of $20 \mathrm{t} / \mathrm{h}$ CHB. Similarly, the highest growth performance of faba bean including plant height, leaf number, chlorophyll content, nodulation number, root and shoot biomass, uptake of $\mathrm{N}, \mathrm{P}$ and $\mathrm{K}$ were recorded from biochar-amended soil. From this study, it can be suggested that the application of biochar could be an alternative promising amendment to lime for acid soil management and sustainable crop production. But, further investigations need to be continued under field conditions across different soil and crop types.
\end{abstract}

Keywords: Amelioration, Coffee Husk Biochar, Faba Bean, Nitisols

\section{Introduction}

Agricultural soils have major constraints related to soil fertility and plant nutrient managements likewise deficiencies of essential trace elements and macro-nutrients and these deficiencies can affect the nutritional quality of edible crops with direct consequences for human health [1]. Cause of Soil degradation processes including soil erosion, organic matter, and plant nutrient depletion, nutrient imbalances, application of inorganic fertilizer, acidity of Soil and fixation of phosphors in the highlands area of Ethiopia are among the major challenges affecting agricultural productivity and quantity of food issue [2-4]. Fortunately, these problems can be resolved by the application of biochar as soil amendments that can be sequestered for hundreds of years in the soil [5]. Recent studies have suggested that the soil amended with biochar can potentially enhance agronomic productivity [6].
Biochar refers to the carbonaceous product obtained by thermal heating of plant or animal residue in an oxygenlimited atmosphere and when applied to soil use to development of nutrient status [7] it consists a potential to retain nutrients for plant uptake and soil fertility enrich plant growth and yield [8]. It also helps to improve agricultural production by reducing P-fixation and to change biological activity and other pysico- chemical property of soil owing enhancing soil $\mathrm{pH}$, soil porosity, CEC, fertilizer-use efficiency, nutrient retention, availability. Not only increment of soil nutrient and also Decrease nutrient leaching [2, 3], water retention capacity [9] and enhanced plant-available water content [10], and by creating suitable environment for beneficial soil microorganisms [11].

Faba bean (ViciafabaL.) is considered one of the most 
important legumes plants play a key role in sustainable agriculture production and present economic and environmental benefits due to their important capacity to fix nitrogen from the atmosphere in the root nodules in a symbiotic relationship with rhizobia. Also, Faba bean is among the major grain food legumes cultivated in a different part of Ethiopia and used in worldwide as an important source of protein for human and animal nutrition [12]. Thus the productivity of this crop is constrained by low $\mathrm{P}$ availability associated with low soil $\mathrm{P}^{\mathrm{H}}$. Acid soils occur widely in the highlands of Ethiopia where the rainfall intensity is high and the land has been under farming for many years. These soils have $\mathrm{P}^{\mathrm{H}}$ values of less than 5.5; availability of $\mathrm{P}$ and other soil nutrients are fixed which result in low faba bean yields. The low yields in such soils could mainly be either due to the deficiency of soil macronutrients [13], or toxicity of Al, Fe and $\mathrm{Mn}$ [14]. As a result, $\mathrm{P}$ deficiency is one of the most widespread soil constraints in these soils. Furthermore, Agegnehu [15] reported that acid soils could expose faba bean to greater chocolate spot infection thereby reducing yield.

The drawback of Soil nutrient depletion and acidic soil can be managed by using the application of synthetic fertilizer and different lime materials. However, cost of limestone material and fertilizer increased time to time and challenge to the Ethiopia farmers. Not only has the lime supply limited and also only amend exchangeable calcium, magnesium, and phosphorus. Owing to this, some investigators have recently started using biochar and organic fertilizer (compost and bio-fertilizer) as an alternative soil amendment mechanism. The biochar materials can increases crop yield, its farmers easily accessible, inexpensive once pyrolysis mashing buy or to prepared locally compared to limestone and chemical fertilizer and ecologically friend. Therefore, the aims of this study were, to test effect of the application of coffee husk biochar on nitisol 1) the response of faba bean growth (agronomic data) and nutrient uptake, 2) effect of soil nutrient properties.

\section{Materials and Methods}

\subsection{Description of the Study Area}

The study was conducted at Holetta agricultural research center in greenhouse and geographically located at $09^{\circ} \mathrm{N}$, $38^{\circ} \mathrm{E}$ at an altitude of $2400 \mathrm{~m}$ above sea level and characterized with a mean annual rainfall of $1044 \mathrm{~mm}$, mean relative humidity of $60.6 \%$ and mean maximum and minimum temperature of $22.1^{\circ} \mathrm{C}$ and $6.2^{\circ} \mathrm{C}$, respectively. The dominant soils of the area are reported to be Nitisols which are sesquioxidic and moderately to strongly acidic [16].

\subsection{Sample Collection and Preparation}

Before sampling, there was done assessment for identification of exact area of the soil acidity problem by measuring soil $\mathrm{pH}$ in laboratory. Then for pot experiment and
Pre-planting soil nutrients analysis composite soil sample $(0$ $20 \mathrm{~cm}$ depth) at five points in zigzag pattern was collected using an auger, core samplers were used for bulk density sampling separately from the place of soil $\mathrm{pH}$ below 5 . The collected sample kept in polyethylene bags. Coffee husk biochar was taken from Jimma University College of Agriculture and Veterinary Medicine and the collected soil and biochar sample were transferred to plastic trays and break up the large clods to speed up drying. The sample was air-dried, crushed with mortar and pestle and passed through a $2 \mathrm{~mm}$ opening stainless steel sieve [17].

\subsection{Method of Soil Physico-chemical Properties Analysis}

All analytical measurement was performed at Holetta Agricultural Research Laboratory. The soil $\mathrm{pH}$ was measured potentiometric with a digital $\mathrm{pH}$ meter in the supernatant suspension of 1:2.5 soils to water ratio [18]. Exchangeable basic ( $\mathrm{K}, \mathrm{Na}, \mathrm{Ca}$ and $\mathrm{Mg}$ ) ions were extracted using $1 \mathrm{M}$ ammonium acetate extraction buffered at $\mathrm{pH} 7$ using mechanical shaking and followed by measuring the concentration in atomic absorption spectrophotometer. Micronutrients were extracted using DTPA extraction and extractant were read with AAS instrument. Total Nitrogen content in shoot part and soil was determined by digesting the samples in sulfuric acid $\left(\mathrm{H}_{2} \mathrm{SO}_{4}\right)$ by the Kjeldahl method [19]. Available Phosphorus was determined by Olsen and berry 2 methods using $1 \mathrm{~g}$ of air dry soil in $20 \mathrm{ml}$ of $0.5 \mathrm{M}$ $\mathrm{NaHCO}_{3}$ (pH 8.5) shaking for 30 minutes [20] and by shaking $2 \mathrm{~g}$ of air dry soil in $20 \mathrm{ml}$ of extracting solution $\left(0.03 \mathrm{M} \mathrm{NH}_{4} \mathrm{~F}\right.$ and $\left.0.1 \mathrm{M} \mathrm{HCl}\right)$ followed by measuring the Phosphorus concentration in the spectrophotometer.

\subsection{Experimental Setup}

The type of soil used for all pots was nitisols and $3 \mathrm{~kg}$ of prepared soil was filled in plastic pots. Each pot has four holes at the bottom and was equipped with a sealable plastic bag. Each treatment's applied on the plastic pot before planting and mechanically mixed into soil and the treatments were incubated for three weeks at $50 \%$ water holding capacity. The experiments were employed in a greenhouse in a randomized complete block design (RCBD). 8 faba bean seeds (cultivar Tumsa) were sowed to a depth of $4 \mathrm{~cm}$ in the pots and thinned to 4 plants per pot after seedling emergence. The moisture content of the trial pots was maintained at field capacity by adding water until soil samples were collected after harvest time. For this study ten treatments were used; each treatment was replicated 4 times, giving a total of 40 pots. The treatments were: 1) Control soil; 2) Recommended phosphorus fertilizer only (RPF) as positive control; 3) Coffee husk biochar $(10 \mathrm{t} / \mathrm{h})+\mathrm{RPF})$; 4) Coffee husk biochar $(20 \mathrm{t} / \mathrm{h})+\mathrm{RPF} ; 5)$ Coffee husk biochar $(10 \mathrm{t} / \mathrm{h})+50 \% \mathrm{RPF} ; 6)$ Coffee husk biochar $(20 \mathrm{t} / \mathrm{h})+50 \% \mathrm{RPF} ; 7)$ Lime + RPF; 8) Lime $+50 \%$ RPF; 9) 50\% lime + biochar $10 \mathrm{t} / \mathrm{h}+\mathrm{RPF} ; 10)$ $50 \%$ lime + biochar $10 \mathrm{t} / \mathrm{h}+50 \% \mathrm{RPF}$. 


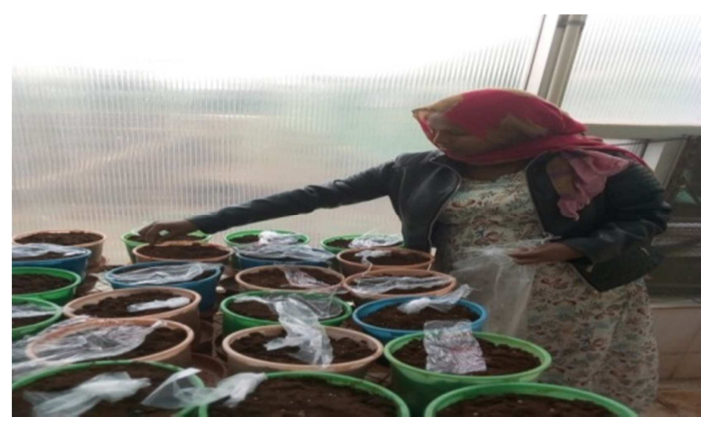

Figure 1. Treatment application in greenhouses pot experiment.

\subsection{Agronomic Data Collection and Measurement}

Agronomic data was recorded on a random sample of plants, taken from all four replicates of each treatment. Plant height was recorded from the base of the stem at soil level to the final shoot of the plant of a fully opened leaf on the main shoot and the mean height was expressed in $\mathrm{cm}$. Plant height was recorded at flowering stage of Days after germination. A number of leaves and nodulation No on each tagged plant were counted manually at the flowering stage. Relative leaf chlorophyll content was measured using a chlorophyll meter (SPAD-502). For each chlorophyll measurement, duplicate readings were made on the second fully expanded leaf from the top of the Main plant stem. The dry weight of root and total above ground biomass were measured after $48-72 \mathrm{hrs}$. The shoot part of the plant Dried in the oven at $70^{\circ} \mathrm{C}$ and after these taken for elemental analysis.

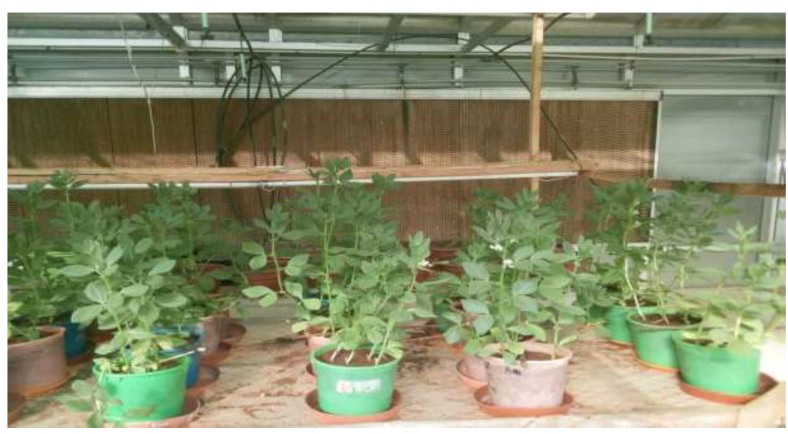

Figure 2. Growth stage in green house

\section{Results and Discussions}

Table 1. Property of soil and coffee husk biochar before planting (Mean $\pm S D$ ).

\begin{tabular}{llll}
\hline Nutrients & & & Biochar sample \\
\hline Properties & SI Unit & Soil sample & 11.05 \\
$\mathrm{pH}$ & $\left.\mathrm{Soil}_{\mathrm{H}} \mathrm{H}_{2} \mathrm{O} 1: 2.5\right)$ biochar $(1: 5)$ & 4.89 & $16.23 \pm 0.169$ \\
$\mathrm{Ca}$ & $\mathrm{Cmol}_{\mathrm{c}} \mathrm{kg}$ & $7.283 \pm 0.5$ & $7.63 \pm 0.09$ \\
$\mathrm{Mg}$ & $\mathrm{Cmol}_{\mathrm{c}} / \mathrm{kg}$ & $3.865 \pm 0.035$ & $243 \pm 1.17$ \\
$\mathrm{~K}$ & $\mathrm{Cmol}_{\mathrm{c}} / \mathrm{kg}$ & $2.09 \pm 0.21$ & $0.0388 \pm 0.0006$ \\
$\mathrm{Na}$ & $\mathrm{Cmol} / \mathrm{kg}$ & $0.296 \pm 0.004$ & $0.55 \pm 0.008$ \\
$\mathrm{Cu}$ & $\mathrm{Mg} / \mathrm{kg}$ soil & $4.32 \pm 0.07$ & $56.4 \pm 1.49$ \\
$\mathrm{Fe}$ & $\mathrm{Mg} / \mathrm{kg}$ soil & $263.9 \pm 1.15$ & $0.286 \pm 0.09$ \\
$\mathrm{Mn}$ & $\mathrm{Mg} / \mathrm{kg}$ soil & $117.69 \pm 1.7$ & $0.23 \pm 0.02$ \\
$\mathrm{Zn}$ & $\mathrm{Mg} / \mathrm{kg}$ soil & $1.1 \pm 0.03$ & 0.62 \\
$\mathrm{TN}$ & $\%$ & 0.11 & 1109 \\
\hline
\end{tabular}

The initial concentration before planting of micronutrients in the soil such as $\mathrm{Fe}, \mathrm{Mn}, \mathrm{Cu}$, and $\mathrm{Zn}$ are 263.9, 117.69, 4.32 and $1.1 \mathrm{Mg} / \mathrm{kg}$ soil respectively. The value of macronutrients such as $\mathrm{Ca}, \mathrm{K}, \mathrm{Na}$, and $\mathrm{Mg}$ are 7.28, 2.1, 0.296 and 3.86 $\mathrm{Mg} / \mathrm{kg}$ soil respectively. In biochar sample use as amendment, the values of available $\mathrm{K}(243 \mathrm{Cmol} / \mathrm{kg}), \mathrm{P}(1109 \mathrm{Mg} / \mathrm{kg})$ is approximately similar with the report of this finding with which is observed by Dume et al [21]. Ca and $\mathrm{Mg}$ and $\mathrm{Na}$ value is $16.23,7.63$, and 0.039 , respectively.

Table 2. Effect of biochar on the growth parameter of faba bean.

\begin{tabular}{|c|c|c|c|c|c|c|}
\hline \multirow[b]{2}{*}{ Treatment } & \multicolumn{6}{|c|}{ Growth parameter } \\
\hline & Leaf number & $\begin{array}{l}\text { Plant height } \\
\text { (cm) }\end{array}$ & $\begin{array}{l}\text { Root biomass } \\
\text { (g) }\end{array}$ & $\begin{array}{l}\text { Shoot biomass } \\
\text { (g) }\end{array}$ & $\begin{array}{l}\text { Chlorophyll } \\
\text { content }\end{array}$ & $\begin{array}{l}\text { Nodule number } \\
\text { per plant }\end{array}$ \\
\hline Con & $26.78^{\mathrm{h}}$ & $57.01^{\mathrm{f}}$ & $1.995^{\mathrm{j}}$ & $2.62^{\mathrm{h}}$ & $28.70^{\mathrm{e}}$ & $34.25^{\mathrm{e}}$ \\
\hline RPF & $29.63^{\mathrm{g}}$ & $58.87^{\mathrm{ef}}$ & $2.17^{\mathrm{i}}$ & $2.73^{\mathrm{g}}$ & $29.7^{\mathrm{e}}$ & $35.25^{\mathrm{e}}$ \\
\hline CHB $(10 t / h)+R P F$ & $32.28^{\text {ed }}$ & $61.0^{\mathrm{cd}}$ & $2.61^{\mathrm{e}}$ & $2.94^{\mathrm{de}}$ & $34.65^{\mathrm{c}}$ & $41^{\mathrm{c}}$ \\
\hline CHB $(20 t / h)+R P F$ & $38.83^{\mathrm{a}}$ & $65.0^{\mathrm{a}}$ & $3.59^{\mathrm{a}}$ & $3.72^{\mathrm{a}}$ & $39.18^{\mathrm{a}}$ & $79^{\mathrm{a}}$ \\
\hline CHB $(10 \mathrm{t} / \mathrm{h})+50 \% \mathrm{RPF}$ & $31.37^{\text {edf }}$ & $60.35^{\mathrm{d}}$ & $2.55^{\mathrm{f}}$ & $2.87^{\mathrm{ef}}$ & $34.58^{\mathrm{c}}$ & $40^{\text {cd }}$ \\
\hline $\mathrm{CHB}(20 \mathrm{t} / \mathrm{h})+50 \% \mathrm{RPF}$ & $37.1^{\mathrm{b}}$ & $63.03^{\mathrm{b}}$ & $3.52^{\mathrm{b}}$ & $3.59^{\mathrm{b}}$ & $39.08^{\mathrm{a}}$ & $78.25^{\mathrm{a}}$ \\
\hline Lime + RPF & $31.32^{\mathrm{ef}}$ & $59.03^{\mathrm{e}}$ & $2.22^{\mathrm{g}}$ & $2.87^{\mathrm{ef}}$ & $33.43^{\mathrm{d}}$ & $39.25^{\mathrm{dc}}$ \\
\hline Lime $+50 \%$ RPF & $30.58^{\mathrm{gf}}$ & $58.82^{\mathrm{e}}$ & $2.15^{\mathrm{h}}$ & $2.83^{\mathrm{f}}$ & $33.50^{\mathrm{d}}$ & $38^{\mathrm{fd}}$ \\
\hline CHB $(10 \mathrm{t} / \mathrm{h})+50 \%$ lime $+\mathrm{RPF}$ & $33.48^{\mathrm{c}}$ & $62.20^{\mathrm{b}}$ & $2.9^{\mathrm{c}}$ & $3.06^{\mathrm{c}}$ & $35.65^{\mathrm{b}}$ & $50.25^{\mathrm{b}}$ \\
\hline CHB $(10 \mathrm{t} / \mathrm{h})+50 \%$ lime $+50 \%$ RPF & $32.37^{\mathrm{d}}$ & $61.25^{\mathrm{cd}}$ & $2.86^{\mathrm{d}}$ & $2.96^{\mathrm{d}}$ & $35.38^{\mathrm{b}}$ & $50.25^{\mathrm{b}}$ \\
\hline $\operatorname{LSD}(0.05)$ & 1.006 & 1.2 & 0.04 & 0.08 & 0.67 & 2.1 \\
\hline $\mathrm{CV}(\%)$ & 2.13 & 1.35 & 0.98 & 1.69 & 1.34 & 2.95 \\
\hline
\end{tabular}




\subsection{Effect of Biochar on Leaf Number, Plant Height, Root and Shoot Biomass}

The addition of biochar combined with mineral fertilizer in nitisol can improve on the most growth parameters of faba bean as compared to untreated soil. Leaf number, plant height, Chlorophyll content, Nodule number per plant, Root and shoot biomass were significantly higher at $(\mathrm{P}<0.05)$ in the application of $20 \mathrm{t} / \mathrm{h} \mathrm{CHB}+\mathrm{RPF}$ and $20 \mathrm{t} / \mathrm{h} \mathrm{CHB}+50 \% \mathrm{RPF}$ than other treatments. The highest values of leaf number and plant height increase by 31 and $12 \%$, as compared to the control and $23 \%$ and $9 \%$ as compared to mineral fertilizer only respectively and increasing value of shoot and root biomass respectively $2-28 \%$ and $2-44 \%$ as compared to the control. The observed increase value either owing to the addition of biochar in the existence of having a greater amount of primary nutrient ( $\mathrm{k}$ and $\mathrm{p}$ ) or due to liming effect to making available $\mathrm{P}$ in addition to supplying nutrient to reduced exchangeable acidity (Aluminum toxicity) and some micronutrient to be detrimental to root and plant growth and favorable $\mathrm{pH}$ range $(>5.5)$ for faba bean growth, or (improving chemically, physically and biological properties of soil leads to good soil structure, aeration, porosity, and transportation of available nutrient through the root system. This properties also speed up the microbial reactions and provides micro and macro elements for plant production. These results in crop performance are corresponding with other studies [22].

\subsection{Effect of Biochar on Chlorophyll Content}

Chlorophyll is a light-absorbing pigment (chloroform molecules), and it actually gets its green color since it absorbs blue and red wavelengths of light. The green wavelengths are reflected, giving that particular color to plants and also they related to the $\mathrm{N}$ content in green plants and helps as a measure of the response of crops to $\mathrm{N}$ fertilizer application and soil nutrient status subsequently deficiency of nitrogen leads to loss green color in the leaves, decrease leaf area and intensity of photosynthesis. Data in Table 2 show that effect of biochar application to soil; significantly change at $(p \leq 0.05)$ increased the mean values of chlorophyll in a plant grown as compared with the untreated plants.

Similarly, chlorophyll content on the application of lime in acid soil showed significant change but not mineral fertilizer alone is insignificant. In other words; the highest values were recorded in the application of $20 \mathrm{t} / \mathrm{h} \mathrm{CHB}$ and increased by a factor of $27 \%$ than control. The increase in leaf chlorophyll content with the plant due to the addition of biochar better to the availability of nutrients and improvement of soil structure such as surface area, porosity, soil reaction, and such properties to makes suitable condition for soil microbial activity. Microbial activity is good decomposer of organic materials that increased $\mathrm{N}$ content of faba bean. So this result endorsed in Chlorophyll content, a pointer of photosynthetic activity is related to the $\mathrm{N}$ content in green plants and serves as a measure of the response of crops to $\mathrm{N}$ fertilizer application and soil nutrient status. The report of this finding is similar with the result which is observed by Adekayode and Olojugba [23].

\subsection{Effect of Biochar on Nodulation Number}

Table 2 has shown that all faba bean plants under the different rate of treatments including control showed nodulation may be the inoculation of their seeds with rhizobia, which were responsible for nodulation. The lowest values of nodulation parameters were observed in faba bean under nobiochar application. On the other hand, higher values of nodule number were observed under the treatments of $20 \mathrm{t} / \mathrm{h} \mathrm{CHB}+$ $\mathrm{RPF}$ and $20 \mathrm{t} / \mathrm{h} \mathrm{CHB}+50 \%$ RPF. Range of nodulation number in plant cultivated in amended soil with biochar was found $6 \%$ to $57 \%$ increase compared to control. Addition of lime combines with mineral fertilizer also shows significant value on nodulation number of faba bean.

This positive effect of the application of biochar it may be due to the result of promoting the efficiency of inoculants or native microorganisms, and increasing soil $\mathrm{pH}$ also enhanced mediated microorganisms. The report of this finding is similar with the result which is observed by Quilliam et al [24], possibly through the release of its labile organic matter, which may have caused immobilization of $\mathrm{N}$ [25].

\subsection{Effect of Biochar on Nutrient (N, P, and K) Uptakes of Faba Bean}

Results of the shoot part of analyses for their N, P and K contents (\%) have listed in Table 3. From the table the application of the different amount of biochar amendments on the nutrient uptake of $\mathrm{N}, \mathrm{P}$, and $\mathrm{K}$ is a significantly at ( $\mathrm{p} \leq$ 0.05 ) positive effect as compared to control. These indicate that the application of different treatment supported nutrient uptake of faba bean in the soil solution. N, P, K is the primary nutrient for plant. Most agricultural plants primarily take up inorganic $\mathrm{N}, \mathrm{P}, \mathrm{K}$ which comes from the conversion of organic form to inorganic form (mineralization), although a few crop species like faba bean were observed to directly take up organic $\mathrm{N}$ for energy and growth.

Both $20 \mathrm{t} / \mathrm{h} \mathrm{CHB}+\mathrm{RPF}$ and $20 \mathrm{t} / \mathrm{h} \mathrm{CHB}+50 \% \mathrm{RPF}$ were showed highest value of $\% \mathrm{~N}$ content than with the other treatments but does not showed a statistically significant difference between them. Generally the application of biochar and lime showed a statistically significant difference on the value of $\% \mathrm{~N}$ content compared to control. The lowest value of $\mathrm{N}$ uptake obtained from the control (1.43) and highest value 3.28 at the rate of $20 \mathrm{t} / \mathrm{h}$ biochar. The positive effect of this result indicated due to the addition of biochar to improve soil nutrient solubility, availability, porosity, surface area, soil reaction, water uptake and transportation by the plants through root systems. Since acid soil toxicity of $\mathrm{Al}^{3+}$ is one of the major limiting factors for crop production by inhibiting root cell division and elongation, reducing water and nutrient uptake. The functions of Biochar not only provide nutrients but also improve biological aspects of soil 
fertility and crated optimum condition for active microorganism. The report of this finding is similar with the result which was observed by Roberts et al [1, 2, 25, 26]. Since the solubility of a complex form of iron and aluminum phosphate in soil solution and, due to microbial activity conversation of organic $\mathrm{N}$ to the inorganic form of $\mathrm{NO}_{3}^{-}-\mathrm{N}$ and $\mathrm{NH}_{4}{ }^{+}-\mathrm{N}$ increase with soil $\mathrm{pH}$. In acidic soil solubility of $\mathrm{Al}$ increase can be toxic to rhizobia and plant roots, limiting legume production of $\mathrm{N}$.

Table 3. Nutrient uptake of faba bean under different treatment (Mean $\pm S D$ ).

\begin{tabular}{llll}
\hline \multirow{2}{*}{ Treatment } & nutrient uptake of plant & & \\
\cline { 2 - 4 } & $\mathbf{\% N}$ & $\mathbf{\%}$ & $\mathbf{\%}$ \\
\hline Con & $1.43 \pm 0.13^{\mathrm{e}}$ & $0.084 \pm 0.013^{\mathrm{g}}$ & $2.32 \pm .023^{\mathrm{f}}$ \\
RPF & $1.423 \pm 0.1^{\mathrm{e}}$ & $0.109 \pm 0.011^{\mathrm{f}}$ & $2.35 \pm 0.029^{\mathrm{f}}$ \\
CHB $(10 \mathrm{t} / \mathrm{h})+$ RPF & $2.23 \pm 0.04^{\mathrm{c}}$ & $0.13 \pm 0.01^{\mathrm{e}}$ & $4.15 \pm 0.034^{\mathrm{d}}$ \\
CHB $(20 \mathrm{t} / \mathrm{h})+$ RPF & $3.28 \pm 0.008^{\mathrm{a}}$ & $0.16 \pm 0.054^{\mathrm{a}}$ & $4.71 \pm 0.099^{\mathrm{a}}$ \\
CHB $(10 \mathrm{t} / \mathrm{h})+50 \%$ RPF & $2.22 \pm 0.05^{\mathrm{c}}$ & $0.12 \pm 0.005^{\mathrm{e}}$ & $4.12 \pm 0.02^{\mathrm{d}}$ \\
CHB $(20 \mathrm{t} / \mathrm{h})+50 \%$ RPF & $3.28 \pm 0.08^{\mathrm{a}}$ & $0.15 \pm 0.003^{\mathrm{b}}$ & $4.65 \pm 0.04^{\mathrm{b}}$ \\
Lime + RPF & $1.83 \pm 0.03^{\mathrm{d}}$ & $0.113 \pm 0.001^{\mathrm{ef}}$ & $3.97 \pm 0.02^{\mathrm{e}}$ \\
Lime $+50 \%$ RPF & $1.78 \pm 0.12^{\mathrm{d}}$ & $0.105 \pm 0.005^{\mathrm{f}}$ & $3.95 \pm 0.03^{\mathrm{e}}$ \\
CHB $(10 \mathrm{t} / \mathrm{h})+50 \%$ lime + RPF & $2.51 \pm 0.01^{\mathrm{b}}$ & $0.146 \pm 0.001^{\mathrm{bc}}$ & $4.28 \pm 0.02^{\mathrm{c}}$ \\
CHB $(10 \mathrm{t} / \mathrm{h})+50 \%$ lime $+50 \%$ RPF & $2.46 \pm 0.02^{\mathrm{b}}$ & $0.14 \pm 0.003^{\mathrm{c}}$ & $4.25 \pm 0.02^{\mathrm{c}}$ \\
LSD $(0.05)$ & 0.12 & 0.009 & 0.057 \\
CV $(\%)$ & 3.58 & 4.85 & 1.01 \\
\hline
\end{tabular}

Abbreviations refer to LSD; least significant difference; CV the coefficient of variation. Within columns, means followed by the same letter are not significantly different at $P=0.05$.

Similar result is observed on P-uptake of faba bean as compared to the control experiment (Table 3). This might be due to increased soil $\mathrm{pH}$ as a result of lime application of biochar, which enhances the release of phosphate ions fixed by $\mathrm{Al}$ and $\mathrm{Fe}$ ions into the soil solution in addition to its Capacity to supply soil nutrients and increased the absorption of $\mathrm{P}$ by faba bean compared to the control. Similarly, application of lime together with full and half recommended mineral fertilizer ( $p$ ) increased P-uptake of faba bean treated with the respective levels as compared to control.

Table 3 shown positive increments indicated due to the acid neutralizing capacity of lime. Related to N-uptake, the highest P-uptake $0.16 \%, 0.15 \%$ was obtained from the application of Biochar on the rate of treatment $20 \mathrm{t} / \mathrm{h} \mathrm{CHB}+$ $\mathrm{RPF}$ and $20 \mathrm{t} / \mathrm{h} \mathrm{CHB}+50 \% \mathrm{RPF}$ respectively, while, the lowest $(0.084 \%)$ was obtained from the control (Table 3$)$.
Phosphorus content of the shoot biomass recorded from 20 $\mathrm{t} / \mathrm{h} \mathrm{CHB}+\mathrm{RPF}$ and $20 \mathrm{t} / \mathrm{h} \mathrm{CHB}+50 \% \mathrm{RPF}$ greater by a factor of 48 and 44 respectively that of the control. These result indicated both treatments between the combination of biochar and lime with mineral fertilizer and mineral fertilizer alone are shown $\mathrm{P}$ uptake of faba bean due to direct transport of available phosphors through root system from it.

Like to the $\%$ content of $\mathrm{N}$ available $\mathrm{K}$ was shown a significant change in the application of the rate of biochar and lime at $(\mathrm{P}<0.05)$ compared to control and mineral fertilizer alone. The increment of the result due to the addition of biochar supply $\mathrm{K}$ nutrient to plant root and may be due to the rise of soil $\mathrm{pH}$, Plant macronutrient dependent on soil $\mathrm{pH}$. Similar explanations were reported by Agegnehu et al $[2,21,27]$.

Table 4. Soil nutrient after crop harvesting.

\begin{tabular}{|c|c|c|c|c|c|c|}
\hline \multirow{2}{*}{ Treatments } & \multicolumn{6}{|c|}{ Exchangeable cations (Cmole/kg) } \\
\hline & Ca & Mg & $\mathbf{N a}$ & $\mathbf{K}$ & TN (\%) & $\mathrm{P}(\mathrm{mg} / \mathrm{kg})$ \\
\hline Con & $5.88^{f}$ & $4.22^{\mathrm{f}}$ & $0.292^{\mathrm{a}}$ & $1.03^{\mathrm{g}}$ & $0.11^{\mathrm{d}}$ & $7.48^{\mathrm{H}}$ \\
\hline RPF & $6.1^{\mathrm{f}}$ & $4.2^{\mathrm{f}}$ & $0.298^{\mathrm{a}}$ & $1.2^{\mathrm{f}}$ & $0.11^{\mathrm{d}}$ & $8.388^{\mathrm{g}}$ \\
\hline CHB $(10 t / h)+R P F$ & $6.45^{\mathrm{dc}}$ & $4.77^{\mathrm{c}}$ & $0.293^{\mathrm{a}}$ & $2.89^{\mathrm{c}}$ & $0.135^{\mathrm{c}}$ & $9.48^{\mathrm{e}}$ \\
\hline $\mathrm{CHB}(20 \mathrm{t} / \mathrm{h})+\mathrm{RPF}$ & $7.5^{\mathrm{a}}$ & $5.04^{\mathrm{a}}$ & $0.292^{\mathrm{a}}$ & $6.7^{\mathrm{a}}$ & $0.165^{\mathrm{a}}$ & $13.564^{\mathrm{a}}$ \\
\hline $\mathrm{CHB}(10 \mathrm{t} / \mathrm{h})+50 \% \mathrm{RPF}$ & $6.58^{\mathrm{cb}}$ & $4.78^{\mathrm{c}}$ & $0.296^{\mathrm{a}}$ & $2.86^{\mathrm{c}}$ & $0.135^{\mathrm{c}}$ & $9.169^{\text {ef }}$ \\
\hline $\mathrm{CHB}(20 \mathrm{t} / \mathrm{h})+50 \% \mathrm{RPF}$ & $7.55^{\mathrm{a}}$ & $4.99^{\mathrm{a}}$ & $0.293^{\mathrm{a}}$ & $6.58^{\mathrm{a}}$ & $0.147^{\mathrm{b}}$ & $11.97^{\mathrm{b}}$ \\
\hline Lime + RPF & $6.21^{\mathrm{ed}}$ & $4.47^{\mathrm{e}}$ & $0.279^{\mathrm{a}}$ & $1.61^{\mathrm{d}}$ & $0.113^{\mathrm{d}}$ & $9.17^{\mathrm{ef}}$ \\
\hline Lime $+50 \%$ RPF & $6.25^{\mathrm{ed}}$ & $4.54^{\mathrm{d}}$ & $0.295^{\mathrm{a}}$ & $1.6^{\mathrm{d}}$ & $0.113^{\mathrm{d}}$ & $8.822^{\mathrm{g}}$ \\
\hline $\mathrm{CHB}(10 \mathrm{t} / \mathrm{h})+50 \%$ lime $+\mathrm{RPF}$ & $6.77^{\mathrm{b}}$ & $4.84^{\mathrm{b}}$ & $0.286^{\mathrm{a}}$ & $3.47^{b}$ & $0.13^{\mathrm{c}}$ & $10.944^{\mathrm{c}}$ \\
\hline CHB $(10 \mathrm{t} / \mathrm{h})+50 \%$ lime $+50 \% \mathrm{RPF}$ & $6.73^{\mathrm{b}}$ & $4.86^{\mathrm{b}}$ & $0.293^{\mathrm{a}}$ & $3.37^{\mathrm{b}}$ & $0.13^{\mathrm{c}}$ & $10.393^{\mathrm{d}}$ \\
\hline $\operatorname{LSD}(0.05)$ & 0.28 & 0.059 & 0.021 & 0.16 & 0.007 & 0.471 \\
\hline $\mathrm{CV}(\%)$ & 2.89 & 0.86 & 4.97 & 3.55 & 4.11 & 3.266 \\
\hline
\end{tabular}

CHB; Coffee husk biochar; RPF; Recommended phosphorus; LSD, least significant difference; CV, the coefficient of Variation. Within columns means followed by the same letter are not significantly different at $P=0.05$.

These results indicated enhance of soil exchangeable base such as $\mathrm{K}, \mathrm{Ca}$ and $\mathrm{Mg}$ but the application of biochar in soil was not a significantly positive effect on the property of soil exchangeable $\mathrm{Na}^{+}$. The treatment of biochar in soil, 
exchangeable $\mathrm{K}$ more improves when compared to the other three elements. The application rate of biochar increase with increased availability of soil exchangeable K. Addition of 20 $\mathrm{t} / \mathrm{h}$ CHB the highest value of exchangeable $\mathrm{K}^{+}$compare to inorganic fertilizer $(\mathrm{P})$ alone and control and increased by a factor of $82 \%$ and $85 \%$ respectively. In other word, addition of mineral fertilizer for each treatment is not shown a statistically significant difference on the property of soil available nutrient. However, acid soil amended with lime positively influenced on the nutrient availability of soil.
These increment of nutrient availability may be due to the liming effect of the addition of biochar and lime to retained nutrients (reduced leaching of nutrient) and also due to the presence of a maximum amount of available $\mathrm{K}$ in the biochar to release into the soil system due to decomposition and mineralization. The report of this finding is similar with the result which is observed by $[27,28]$. Coffee husk compost contains high organic agricultural residue and potassium was good material for composting process in agricultural products further designate by $[29,30]$.

Table 5. Soil micronutrients crop after harvesting.

\begin{tabular}{|c|c|c|c|c|}
\hline \multirow{2}{*}{ Treatment } & \multicolumn{4}{|c|}{ soil micronutrients $\left(\mathrm{mg} / \mathrm{kg}^{-}\right)$} \\
\hline & $\mathbf{F e}$ & $\mathbf{C u}$ & Mn & Zn \\
\hline Con & $256.3^{\mathrm{a}}$ & $4.31^{\mathrm{a}}$ & $112.9^{\mathrm{a}}$ & $1.68^{\mathrm{a}}$ \\
\hline RPF & $254.9^{\mathrm{b}}$ & $4.26^{\mathrm{a}}$ & $113.88^{\mathrm{a}}$ & $1.55^{\mathrm{b}}$ \\
\hline CHB $(10 t / h)+R P F$ & $181^{\mathrm{e}}$ & $3.21^{\mathrm{fg}}$ & $92.1^{\mathrm{c}}$ & $0.83^{\mathrm{e}}$ \\
\hline $\mathrm{CHB}(20 \mathrm{t} / \mathrm{h})+\mathrm{RPF}$ & $175.7^{\mathrm{g}}$ & $3.08^{\mathrm{h}}$ & $82.1^{\mathrm{e}}$ & $0.34^{\mathrm{h}}$ \\
\hline CHB $(10 \mathrm{t} / \mathrm{h})+50 \% \mathrm{RPF}$ & $181.6^{\mathrm{e}}$ & $3.29^{\mathrm{ef}}$ & $92^{\mathrm{c}}$ & $0.88^{\mathrm{d}}$ \\
\hline $\mathrm{CHB}(20 \mathrm{t} / \mathrm{h})+50 \% \mathrm{RPF}$ & $174.9^{\mathrm{g}}$ & $3.13^{\mathrm{gh}}$ & $80.5^{\mathrm{e}}$ & $0.45^{\mathrm{g}}$ \\
\hline Lime + RPF & $222.7^{\mathrm{c}}$ & $3.81^{\mathrm{b}}$ & $103.8^{\mathrm{b}}$ & $1.16^{\mathrm{c}}$ \\
\hline Lime $+50 \%$ RPF & $220.7^{\mathrm{d}}$ & $3.66^{\mathrm{c}}$ & $102.2^{\mathrm{b}}$ & $1.17^{\mathrm{c}}$ \\
\hline $\mathrm{CHB}(10 \mathrm{t} / \mathrm{h})+50 \%$ lime $+\mathrm{RPF}$ & $178.6^{\mathrm{f}}$ & $3.47^{\mathrm{d}}$ & $87 . .2^{\mathrm{d}}$ & $0.64^{\mathrm{f}}$ \\
\hline CHB $(10 \mathrm{t} / \mathrm{h})+50 \%$ lime $+50 \% \mathrm{RPF}$ & $178.9^{\mathrm{f}}$ & $3.38^{\mathrm{ed}}$ & $86.8^{\mathrm{d}}$ & $0.65^{\mathrm{f}}$ \\
\hline $\operatorname{LSD}(0.05)$ & 1.71 & 0.12 & 2.31 & 0.05 \\
\hline $\mathrm{CV}(\%)$ & 0.58 & 2.26 & 1.67 & 3.69 \\
\hline
\end{tabular}

These findings indicate that the effect of biochar on soil micronutrient was significantly reduced at $(\mathrm{P} \leq 0.05)$. micronutrient are trace elements used for plant as nutrient but may also pose a toxicity risk if present at elevated levels as their availability and mobility increases under acidic condition. Application of $20 \mathrm{t} / \mathrm{h}$ CHB reduced the Concentration of iron by $32 \%$ and manganese by $25 \%$ as compared to the control. This observation may be due to the liming effect of biochar addition immobilized the micronutrient in soil by precipitation which reduces the concentration of $\mathrm{Fe}, \mathrm{Cu}, \mathrm{Mn}$, and $\mathrm{Zn}$. From the above discussion of exchangeable acidity reduced due to the addition of biochar and increased soil $\mathrm{p}^{\mathrm{H}}$, as soil $\mathrm{p}^{\mathrm{H}}$ increase rise availability (solubility) of macronutrient and formation of complexes with micronutrient increased. This finding associated with [31] reported that the application of coffee biomass increased soil $\mathrm{pH}$ due to its liming effect. This brought about an increase in cation exchange capacity with a substantial reduction the toxicity of $\mathrm{Al}$ and decrease in the availability of a number of metals $(\mathrm{Cu}, \mathrm{Zn}, \mathrm{Mn}$, and $\mathrm{Fe})$ and significantly reduced their uptake by plant root.

\section{Conclusions}

Initially the study soil was showed that deficient in plantavailable nutrients and application of the biochar and lime significantly positive effect on soil nutrients in addition to nutrient supply, by increasing soil $\mathrm{pH}$ and reduced exchangeable acidity, in a way that enhanced the availability of plant nutrients. Applications of $20 \mathrm{t} / \mathrm{h} \mathrm{CHB}$ were more efficient in improving soil nutrient availability, and nutrient uptake of faba bean than other treatment. The relatively high alkalinity and probably the proton consuming ability of ash materials, as well as the high nutrient contents in biochar, were considered the main factors responsible for the reduced soil acidity and improved nutrient supply of the amended soils. Generally, all the result of soil and plant nutrient obtained with the acceptable analytical methods which were evaluated by using quality assurance method and validation such as precision accuracy, reliability by measurements of replication, method blank, spike recovery was taken.

The positive growth response of the faba bean due to the addition of biochar and lime than control indicated that the soil collected for this research was inherently low in some essential nutrients, hence the level of many essential nutrients in these soils was immovable and lower which was maintained and supplied by biochar and lime amendments. The faba bean was more responsive to the organic source (biochar) amendments compared to the lime, thus indicating there were some important nutrients that were being supplied to the faba bean beside its liming effect. While lime was not used as nutrient sources other than reducing the Aluminum toxicity effect and making the nutrients available for the growth. Liming acid soils result in the release of fixed macronutrients specially phosphorus for plant uptake by decreasing Al. Therefore this investigated research importance as it indicates the value of biochar as alternative amendments to ameliorate soil nutrient and acid soils for small-scale farmers who cannot afford to regularly purchase lime and mineral fertilizers. 


\section{References}

[1] Roberts DA, Paul NA, Cole A J, de Nys R (2015). From waste water treatment to land management Conversion of aquatic biomass to biochar for soil amelioration and the fortification of crops with essential trace elements. Journal of environmental management 157: 60-68.

[2] Agegnehu G, Bass AM, Nelson PN, Muirhead B, Wright G, Bird M I (2015). Biochar and biochar-compost as soil amendments: effects on peanut yield, soil properties and greenhouse gas emissions in tropical North Queensland Australia. Agriculture, Ecosystems \& Environment 213: 72-85.

[3] Agegnehu G, Woldesenbet F (2016). Production of biodegradable plastic by polyhydroxybutyrate (PHB) accumulating bacteria using low-cost agricultural waste material. $B M C$ research notes 9 (1): 509.

[4] Agegnehu G, Yirga C, Erkossa T (2019). Soil Acidity Management. Agriculture and Healthcare 5 (13): 27-32.

[5] Glaser B. Lehmann J. and Zech W. Ameliorating Physical and chemical properties of highly weathered soils in the tropics with charcoal - A Review, Biology and Fertility of Soils, 2002, 35, 219-230.

[6] Akhtar S S, Li G, Andersen M N, Liu F (2014). Biochar enhances yield and quality of tomato under reduced irrigation. Agricultural Water Management 138: 37-44.

[7] Maia CM B, Madari, B E, Novotny E H (2011). Advances in biochar research in Brazil. Embrapa SolosArtigoemperiódicoindexado (ALICE) 75.

[8] Major J, Rondon M, Molina D, Riha S J, Lehmann J (2010). Maize yield and nutrition during 4 years after biochar application to a Colombian savanna oxisol. Plant and soil 333 (1-2): 117-128.

[9] Downie A (2011). Biochar production, use, environmental risks and rewards. Univ South Wales.

[10] Tammeorg P, Simojoki A, Mäkelä P, Stoddard F L, Alakukku L, Helenius J (2014). Short-term effects of biochar on soil properties and wheat yield formation with meat bone meal and inorganic fertilizer on boreal loamy sand. Agriculture, Ecosystems \& Environment 191: 108-116.

[11] Thies J, Rillig M (2009). Characteristics of biochar: Biological properties. temperatures and pressures using biological and botanical samples. Journal of Analytical Chemistry 58 (12): 2534-2541.

[12] Cazzato E, Tufarelli V, Ceci E, Stellacci AM, Laudadio V (2012). Quality, yield and nitrogen fixation of faba bean seeds as affected by sulphur fertilization. Acta Agriculturae Scandinavica Section B-Soil \& Plant Science, 62 (8): 732-738.

[13] Dodd JR, Mallarino AP (2005). Soil-test phosphorus and crop grain yield responses to long-term phosphorus fertilization for corn-soybean rotations. Soil Science Society of America Journal 69 (4): 1118-1128.

[14] Sharma BD, Arora H, Kumar R, Nayyar VK (2004). Relationships between soil characteristics and total and DTPA-extractable micronutrients in Inceptisols of Punjab. Communications in soil science and plant analysis 35 (5-6): 799-818.
[15] Agegnehu G, Bekele T (2005). Phosphorus fertilizer and farmyard manure effects on the growth and yield of Faba Bean and some soil chemical properties in acidic nitisols of the central highlands of Ethiopia. Ethiopian Journal of Natural Resources.

[16] Temesgen D (2015). Effects of short-rotation Eucalyptus plantations on soil quality attributes in highly acidic soils of the central highlands of Ethiopia.

[17] Reeuwijk LP van (2002). Technical paper in procedures in soil analysis. 6th edition.

[18] Huluka G (2005). A Modification of the Adams-Evans Soil Buffer Determination Solution. Communications in Soil Science and Plant Analysis (Vol. 36) pp. 949-951.

[19] Bremner JM, Mulvancy CS (1982). Nitrogen total pp. 595-624. In: A. L Page (Ed). Methods of soil analysis, part two, Chemical and microbiological properties. $2^{\text {nd }}$ ED. American Society of Agronomy, Madison, Wisconsin.

[20] Virgina Cooperative Extension program (2011). Soil testing laboratory procedures. $452-881$.

[21] Dume B, Ayele D, Regassa A, Barecha G (2016). Interactive effects of biochar in soil related to feedstock and pyrolysis temperature. American-Eurasian J Agric Environ Sci, 16: 442448 .

[22] Anteneh Netsere (2015). Response of Coffee (CoffeaarabicaL.) Seedlings to Lime and Phosphorus Mineral Fertilizer at Jimma South western Ethiopia. Journal of Biology, Agriculture and Healthcare, 5 (13): 27-32.

[23] Adekayode FO, Olojugba MR (2010). The utilization of wood ash as manure to reduce the use of mineral fertilizer for improved performance of maize (Zea mays L.) as measured in the chlorophyll content and grain yield. Journal of Soil Science and Environmental Management, 1 (3): 40-45.

[24] Quilliam RS, DeLuca TH, Jones DL (2013). Biochar application reduces nodulation but increases nitrogenase activity in clover. Plant Soil 366: 83-92.

[25] Singh Y, cowie 2014. Management of cereal crop residues for sustainable rice-wheat production system in the Indo-Gangetic plains of India. Proceedings Indian National Academy of Sciences 80: 95-114.

[26] Van Zwieten L, Kimber S, Morris S, Chan KY, Downie A, Rust J, Cowie A (2010). Effects of biochar from slow pyrolysis of papermill waste on agronomic performance and soil fertility. Plant and soil 327 (1-2): 235-246.

[27] Nigussie A, Kissi E, Misganaw M, Ambaw G (2012). Effect of biochar application on soil properties and nutrient uptake of lettuces (Lactuca sativa) grown in chromium polluted soils. American-Eurasian Journal of Agriculture and Environmental Science, 12 (3): 369-376.

[28] Kasongo RK, A Verdoodt, PK anyankogote G Baert EVanRanst. 2011. Coffee waste as an alternative fertilizer with soil improving properties for sandy soils in humid tropical environments. Soil Use and Management, 27: 94-102.

[29] Kasongo RK, A Verdoodt, P Kanyankogote, G. Baert E. VanRanst (2013). The response of Italian Ryegrass (LoliumMultiflorumLam.) to Coffee Waste Application on a Humid Tropical Sandy Soil. Soil Use and Management, 29: 22-29. 
[30] Dzung NA, T Dzung, VTP Khanh (2013). Evaluation of Compost for Improving Soil Fertility and Sustainable Coffee Production in Rural Central Highland of Vietnam. Resources and Environment 3 (4): 77-82.
[31] Henok Kassa and Tenaw Workayehu (201. Evaluation of some additives on coffee residue (coffee husk and pulp) quality as compost, southern Ethiopia. International Invention Journal of Agricultural and Soil Science, 2 (2): 14-21. 